\title{
SUPERVISI KLINIS KEPALA SEKOLAH PENDIDIKAN ANAK USIA DINI ISLAM TERPADU AULADUNA KOTA BENGKULU \\ (Studi Deskriptif Kualitatif di PAUD IT Auladuna Kota Bengkulu)
}

\author{
Uci Pranita \\ ucipranita@gmail.com \\ Nina Kurniah \\ ninakurniah@yahoo.com \\ Anni Suprapti \\ annisuprafti@yahoo.com
}

\begin{abstract}
This study aims to describe the planning of clinical supervision program, stages of clinical supervision implementation, and supporting factors and inhibiting the implementation of clinical supervision in early childhood IT Auladuna Bengkulu City. The method used is descriptive qualitative. Techniques of collecting data through interviews, observation and documentation. Data analysis techniques use interactive models, including: data collection, data reduction, data presentation, and conclusions. Examination of data in this research is done by triangulation of data. The results showed (1) Implementation of principal clinical supervision begins with planning of clinical supervision program and make schedule of supervision. (2) The implementation of clinical supervision is carried out with the initial planning stage, the class observation stage, the reverse meeting stage (reverse discussion). (3) Supporting factors for the implementation of clinical supervision: a) to help overcome the learning problems faced by teachers, b) improve teacher's teaching ability, c) the supervision program created by the principal. Inhibiting factors are: a) the time of clinical supervision has been established but there are other agendas in the school so the implementation should be canceled, b) usually the teacher will be in supervision feel tense so there must be good preparation so that later get good results, c) teachers sometimes feel less ready and disturbed because not yet accustomed supervised clinical.
\end{abstract}

Keywords: Clinical Supervision; School Principal

\section{PENDAHULUAN}

Pendidikan Anak Usia Dini (PAUD) adalah suatu upaya pembinaan yang ditujukan kepada anak sejak lahir sampai usia enam tahun yang dilakukan melalui pemberian rangsangan pendidikan untuk membantu pertumbuhan dan perkembangan jasmani dan rohani agar anak memiliki kesiapan dalam memasuki pendidikan lebih lanjut (UU No. 20 Tahun 2003 Tentang Sisdiknas Pasal 1 Ayat 14).

Pendidikan anak usia dini merupakan pendidikan awal yang berperan penting dalam kehidupan anak. Keberhasilan pendidikan pada jenjang berikutnya ditentukan oleh kualitas pendidikan anak usia dini, sehingga diperlukan adanya penjaminan dan peningkatan mutu pendidikan tersebut. Sehingga taman kanak-kanak harus diselenggarakan sebaikbaiknya melalui perencanaan, pengorganisasian, pengarahan, dan pengawasan yang sistematis seksama, dan berkesinambungan (Bafadal, 2004:71).

Peningkatkan mutu pendidikan harus diawali dengan meningkatkan mutu 
sekolah yang meliputi guru, kepala sekolah dan pengawai sekolah lainnya. Salah satu upaya peningkatan mutu pendidikan tersebut dapat dilakukan melalui pelaksanaan supervisi. Supervisi pendidikan adalah sebagai keseluruhan kegiatan yang bertujuan untuk membantu pengelolaan lembaga pendidikan serta untuk meningkatkan kemampuan guru dan pegawai dalam mengelola lembaga sekolah (Bafadal, 2004:73).

Kepala sekolah memiliki tugas pokok sebagai penanggung jawab kegiatan sekolah, memimpin sekolah dan melakukan supervisi bagi guru dan staf. Sebagaimana Daryanto (2011) mengungkapkan "supervisi adalah salah satu tugas pokok dalam administrasi pendidikan bukan hanya merupakan tugas pekerjaan para pengawas saja melainkan tugas pekerjaan kepala sekolah terhadap pegawaipegawainya".

Supervisi klinis oleh kepala sekolah sekolah merupakan suatu pembimbingan yang bertujuan untuk meningkatkan profesionalitas guru secara sengaja yang dimulai dari tahap perencanaan awal, tahap pelaksanaan observasi kelas dan tahap pertemuan akhir (diskusi balikan) yang dianalisis secara cermat, teliti dan objektif untuk mendapatkan perubahan perilaku mengajar yang diharapkan menurut Makawimbang (2013:26). Supervisi klinis juga dapat dikatakan sebagai supervisi yang di fokuskan pada perbaikan pembelajaran melalui siklus yang sistematis dan di analisis yang intensif terhadap penampilan pembelajaran dengan tujuan untuk memperbaiki proses pembelajaran.

Pelaksanaan supervisi klinis menurut Acheson dan Gall dalam Makawimbang (2013:35) memiliki tujuan, yakni: (1) menyediakan umpan balik yang objektif terhadap guru mengenai pelajaran yang dilaksanakan, (2) mendiagnosis dan membantu memecahkan masalah-masalah pengajaran, (3) membantu guru mengembangkan keterampilannya menggunakan strategi pengajaran, (4) mengoreksi guru untuk kepentingan promosi jabatan ke pentingan lainnya, dan (5) membantu guru mengembangkan satu sikap positif terhadap pengembangan profesional yang berkesinambungan.

Pelaksanaan supervisi klinis sangat diperlukan agar dalam suatu organisasi terciptanya keselarasan tindakan, kesatauan usaha, kesesuaian dan keseimbangan antara unit kerja, dan dapat juga memberikan kontribusi secara optimal dan berarti pada jalannya proses pendidikan.

Berdasarkan wawancara yang

Berdasarkan hasil observasi yang dilaksanakan pada saat Magang III di PAUD IT Auladuna pada bulan Oktober-November 2016, bahwa kepala sekolah setiap paginya datang mengunjungi guru untuk menanyakan kegiatan pembelajaran yang akan dilaksanakan pada hari tersebut. Selanjutnya, setiap hari Jum'at siang kepala sekolah mengadakan diskusi kelompok pada seluruh guru TK tersebut. Dalam pertemuan itu, kepala sekolah dan guru membicarakan banyak hal tentang proses pemebelajaran di sekolah tersebut. Salah satu hal yang dibicarakan yakni mengenai kesulitan yang dihadapi guru dalam pembelajaran. Kesulitan yang dihadapi guru kemudian ditanggapi dengan diberikannya solusi oleh kepala sekolah dan guru lain. Ada juga beberapa guru yang datang menemui kepala sekolah untuk membicarakan tentang kesulitan yang dihadapinya dalam mengajar, guru tersebut meminta bantuan kepala sekolah agar dapat solusi yang tepat mengatasi kesulitan yang dihadapi guru tersebut dalam mengajar. Namun, disini kepala sekolah hanya sebatas memberi solusi dan belum ada ketahap selanjutnya dimana seharusnya pelaksanaan supervisi klinis memiliki tiga tahap paling sedikit yaitu tahap perencanaan awal, pelaksanaan 
observasi kelas, dan tahap akhir (diskusi balik).

Selanjutnya, berdasarkan studi pendahuluan dengan melibatkan proses wawancara dengan kepala sekolah PAUD IT Auladuna Kota Bengkulu di dapat kesimpulan bahwa kesadaran guru akan pentingnya pelaksanaan supervisi klinis masih sangat kurang. Guru cenderung kurang memiliki inisiatif untuk mengajukan pelaksanaan supervisi klinis. Sehingga, kepala sekolah sering kali mengalami kesulitan untuk melaksanakan kegiatan supervisi klinis di sekolah yang di pimpin. Disamping itu, kepala sekola juga cenderung ragu untuk memulai tahapantahapan supervisi klinis di sekolah.

\section{METODE}

Penelitian ini secara khusus bertujuan mendeskripsikan tentang pelaksanaan supervisi klinis kepala sekolah di PAUD IT Auladuna Kota Bengkulu. Adapun lingkup dalam penelitian ini adalah program perencnaan supervisi klinis kepala sekolah, tahapan supervisi klinis, faktor pendukung dan penghambat pelaksanaan dalam supervisi klinis.

Metode penelitian yang digunakan dalam penelitian ini adalah metode deskriptif kualitatif. Metode deskriptif kualitatif diartikan sebagai penelitian yang bermaksud untuk memahami fenomena tentang apa yang dialami subjek penelitian secara menyeluruh yang menghasilkan data deskriptif berupa kata-kata atau lisan (Moleong, 2010:6).

Penelitian ini akan dilaksanakan di PAUD IT Auladuna yang beralamatkan di jalan Semeru RT 04 No.27 Kelurahan Sawah Lebar Kecamatan Ratu Samban Kota Bengkulu.

Prosedur pengumpulan data dan perekaman data dalam penelitian ini menggunakan Observasi ini dilakukan untuk memperoleh data mengenai tahapan supervisi klinis kepala sekolah PAUD IT Auladuna Kota Bengkulu. Wawancara yang akan digunakan dalam penelitian ini untuk menggali mengenai perencanaan program hsupervisi klinis oleh kepala sekolah, tahapan pelaksanaan supervisi klinis dan apa saja faktor pendukung dan penghambat dalam pelaksanaan supervisi klinis kepala sekolah PAUD IT Auladuna Kota Bengkulu. Dokumentasi dilakukan untuk memperoleh data program supervisi kepala sekolah, jadual supervisi kepala sekolah, profile sekolah di PAUD IT Auladuna Kota Bengkulu.

Teknik analisis data menggunakan Model interaktif Miles dan Huberman Sugiyono (2014) dengan langkah-langkah Reduksi data (Data reduction), Penyajian data (Data display), Kesimpulan (Verifikcation).

Pemeriksaan data dalam penelitian ini dilakukan dengan triangulasi data. Triangulasi Sumber Data dan triangulasi Intrumen.

\section{HASIL DAN PEMBAHASAN}

\section{A. Hasil Penelitian}

1. Perencanaan Program Supervisi Klinis Kepala Sekolah PAUD IT Auladuna Kota Bengkulu

Perencanaan supervisi kepala sekolah PAUD IT Auladuna Kota Bengkulu belum memiliki program khusus untuk supervisi klinis tetapi yang ada berupa jadual. Jadual supervisi kepala sekolah yang berisi hari/tanggal, kelas, item supervisi dan keterangan. Jadual supevisi dibuat berdasarkan hasil rapat yang dilakukan di awal tahun pembelajara. Supervisi klinis di PAUD IT Auladuna Kota Bengkulu dibuat dalam kurun waktu satu tahun di bagi dalam dua semester. Setiap satu semester mengadakan supervisi klinis terhadap 15 (lima belas) orang guru dengan terjadual. Guru di PAUD IT Auladuna Kota Bengkulu setiap kelasnya terdiri dari dua orang guru maka di semester berikutnya akan dilaksanakan untuk 15 (lima belas) guru pendamping berikutnya. 
Jadwal supervisi kepala sekolah ini akan diinformasikan kepada seluruh dewan guru PAUD IT Auladuna pada saat rapat kerja (RAKER) yang diadakan awal semester. Pada saat rapat kepala sekolah membagikan jadual supervisi kepala sekolah pada setiap kelas. Jadual yang telah dibagikan oleh kepala sekolah jika terdapat perubahan akan dibertahukan ulang pada saat rapat KBM pada setiap minggunya

Jadual supervisi klinis yang dibuat oleh kepala sekolah PAUD IT Auladuna Kota Bengkulu ini memiliki sasaran untuk seluruh guru baik guru baru maupun guru senior (guru lama) yang mengajar di paud tersebut. Kepala sekolah beranggapan bahwa tidak mesti hanya guru baru di supervisi klinis tapi juga guru lama karena sekolah PAUD yang dipimpinya selalu melakukan pembaruhan terhadap konsep sekolah seperti sekarang ini yaitu neorosains terpan dan metode membaca fonik. Jadi bisa jadi guru senior (lama) tersebut belum menguasai kegiatan baru kita begitupun untuk guru baru maka penting untuk melakukan supervisi klinis ini agar guru selalu update denga pembaruan yang terjadi pada saat ini.

Jadual supervisi klinis ini dibuat atas permintaan guru dan juga atas tawaran dari kepala sekolah. Kepala sekolah menawarkan guru untuk disupervisi klinis atas dasar dari hasil supervisi umumnya yang dinilai memang guru tersebut membutuhkan bantuan karena juga kepala sekolah mempunyai jadual supervisi. Selanjutnya, guru yang datang langsung ke pada kepala sekolah untuk di supervisi memang memiliki permasalahan, dan meminta kepala sekolah melakukan supervisi klinis.

Pelaksanaan supervisi yang sudah dibuat itu dijadualkan secara tegas tetapi dalam pelaksanaannya tidak dapat dilakukan secara tuntas atau secara utuh hanya beberapa dari yang telah dijadualkan dilaksanakan. Semua itu di sebabkan oleh beberapa kendala yaitu kendala waktu, tenaga. Seperti berikut, kadang waktu sudah direncankan tapi ada kegiatan lain kepala sekolah, ada kegiatan di luar kota dan kegiatan yang mendesak harus pada waktu yang bersamaan sehingga mengakibatakan supervisi ini tertuda dan bisa jadi di cancel pelaksanaannya.

\section{Tahapan Supervisi Klinis Kepala Sekolah PAUD IT Auladuna Kota Bengkulu.}

Tahap pelaksanaan supervisi klinis yang dilakukan oleh kepala sekolah PAUD IT Auladuna Kota Bengkulu dimulai dari tahapan perencanaan awal, tahapan pengamatan pembelajaran di kelas dan tahapan diskusi balikan.

a. Tahap pertemuan awal

Pelaksanaan supervisi klinis pada semester ini adalah empat orang guru kelas, dengan permasalahan pembelajaran yang berbeda-beda. Pada guru yang pertama adalah guru tersebut sulit dalam menertipkan anak-anak di dalam kelas pada saat proses pembelajaran. Guru tersebut mendatangi kepala sekolah untuk konsultasi permasalahan yang dihadapinya. Guru menemui kepala sekolah di ruangannya, kepala sekolah menyambut baik kedatangan guru tersebut. Guru mengungkapkan yang menjadi permasalahannya pada saat pembelajaran dan ingin meminta solusi kepada kepala sekolah. Kepala sekolah terlebih dahulu membangun hubungan yang nyaman dan akrab untuk guru agar guru nyaman dalam diskusi tersebut. Namun, Guru dan kepala sekolah sudah terlihat akrab sebelumnya terlihat saat guru dengan leluasa dalam menyampaikan permasalahan yang dihadapinya.

Guru membicarakan bahwa memiliki kesulitan dalam menertipakan anak pada saat pembelajaran berlangsung. Guru tersebut mengajar di kelompok play grop, yang anak-anak masih di usia 3-4 tahun 
susah dalam mendisplinkannya. Guru tersebut menceritakan bagaimana suasana kelas dan berargumen mungkin salah satu penyebabnya adalah kelas yang terbagi dua yang hanya dibatasi oleh lemari panjang tinggi satu meter. Pada proses pembelajaran anak-anak yang mendengar suara dari guru kelas sebelah jadi memebuat anak susah mana suara guru yang harus didengarnya. Selanjutnya kepala memberi saran untuk berdiskusi kepada guru kelas sebelahnya agar ada kesepakatan untuk mengatasi hal ini. Kepala sekolah juga melihat RPPH yang telah dibuat oleh guru apakah sudah sesuai atau belum dengan SOP sekolah tersebut.

Selanjutnya, kepala sekolah dan guru menyepakati kapan waktu untuk pelakasanaan pengamatan pembelajaran dan form penilai yang aka digunakan kepala sekolah pada saat pengamatan pembelajaran.

Pelaksanaan perencanaan awal pada guru kedua yaitu guru kelompok A1. Guru tersebut menemuai kepala sekolah di ruangannya. Kepala sekolah menyambut baik kedatangan guru tersebut, yang memang kedatangan guru tersebut sudah di tunggu oleh kepala sekolah. kepala sekolah membangun hubungan yang nyaman terlebih dahulu agar guru mudah dalam mengungkapkan permasalahan yang dihdapi pada saat pembelajaran. Selanjutnya, guru menyampaiakan kepada kepala sekolah bahwa guru kesulitan dalam membuat intrumen penilaian yang sesuai dengan pembelajaran berbasis neorosains terapan yang menjadi pendekatan pembelajaran di PAUD tersebut. Kemudian kepala sekolah memeriksa RPPH yang sudah dibuat oleh guru untuk melihat intrumen penilaian yang telah dibuat. Kepala sekolah membimbing dan berdiskusi dengan guru untuk mengenai intrumen penilaian. Setelah guru paham mengenai merencang penilai anak Selanjutnya, guru dan kepala sekolah menentukan waktu dan intrumen penilaian untuk pelaksanaan pengamatan pembelajaran.

Pelaksanaan perencanaan awal pada guru ketiga yaitu guru kelas A3. Guru menemui kepala sekolah di runganya, kepala sekolah menyambut baik kedatangan guru dan di persilahkan duduk. Guru membuka pembicaraan maksut kedatangannya ke ruangan bahwa ingin melaksanakan supervisi. Guru ketiga ini mengungkapkan permasalahan yang dihadapinya yaitu susah menarik perhatian anak pada saat menjelaskan kegiatan pembelajaran. Pada saat guru menjelaskan masih ada beberapa anak yang kurang tertarik mendengarkan guru tersebut menjelaskan. Kemudian kepala sekolah menanyakan apa saja yang membuat anak itu tidak mau mendengarkan guru tersebut. Guru menjelaskan kondisi kelas dan setiap anak-anak di kelasnya.

Kepala sekolah dan guru berdiskusi mengenai kemampuan menjelaskan, menanyakan kegiatan pembelajaran yang dibuat guru. Kepala sekolah melihat RPPH yang dibuat oleh guru apakah sudah sesuai dengan SOP sekolah. Kepala sekolah meminta guru memperbaiki sedikit RPPH yang sudah dibuat oleh guru. Saran yang diberikan kepala sekolah adalah guru harus merancang kegiatan yang menarik, guru sedikit mengeraskan suaranya, dan menggunakan media yang menarik untuk menunjang kegaiatan pembelajaran. Kemudian kepala sekolah dan guru menentukan waktu dan intrumen penilaian untuk pelaksanaan pengamatan pembelajaran.

Pelaksanaan perencanaan awal pada guru keempat guru kelompok B1. Guru datang keruang kepala sekolah pada saat anak-anak sudah pulang dari sekolah. kepala sekolah menyambut baik kedatangan guru. guru menyampaiakn maksud kedatangannya menemui kepala sekolah yaitu untuk melaksanakan supervisi. Guru mengungkapkan 
permasalahan yang dihadapinya saat melaksanakan pembelajaran yaitu teknik tanya jawab yang tepat untuk bertanya dengan anak-anak. Guru menjelaskan bahwa saat bertanya dengan anak-anak terlihat anak kurang mengerti dan tidak terlalu antusias mejawab pertanyaan guru. Kepala sekolah memberi saran kepada guru agar pertanyaan yang diberikan kepada anak lebih menarik seperti tentang lingkungan yang paling dekat denganya, intonasi suara dan nada berbicara jelas. Kemudian kepala sekolah melihat RPPH yang telah dibuat oleh guru dan mengoreksinya apakah sudah sesuai dengan SOP sekolah. Setelah semua sudah selasai membahas mengenai permaslahan dan saran sudah diberikan kepala sekolah selanjutnya guru dan kepala sekolah menyepakati intrumen penilain saat pengamatan pembelajaran dan waktu pelaksanaan pengamatan.

b. Tahap pengamatan pembelajaran

Pelaksanaan tahap pengamatan pembelajaran pada guru pertama yaitu guru kelas play group. Kepala sekolah dengan membawa intrumen penilaian guru pada saat proses pembelajaran masuk ke dalam kelas. Intrumen penilaian yang digunakan adalah mencakap seluruh proses pembelajaran dari pembukaan sampai penutupan. Kepala sekolah duduk di belakang bangku anak-anak yang telah disediakan oleh guru kelas. Kepala sekolah mengamati guru tanpa berkomunikasi dengan guru. kepala sekolah terlihat juga mengambil foto dan mengambil video pada saat guru mengajar. selanjutnya, kepala sekolah mengamati proses pembelajaran sampai penutupan kegiatan sentra. Setelah kegiatan sentra selesai kepala keluar ruangan.

Pelaksanaan tahap pengamatan pembelajaran pada guru kelompok A1. Pengamatan dialaksanakan pada pukul 08.20 pada kegiatan sentra. Guru melaksnakan kegiatan seperti biasa yaitu menyambut anak-anak datang ke kelas. Setelah jam masuk kelas semua anak masuk kedalam kelas. Guru telah memberi tahukan kepada anak murid nya bahwa pagi ini kepala sekolah akan masuk ke dalam kelas ini. Kepala sekolah masuk kedalam kelas dengan membawa intrumen penilaian. Kepala sekolah duduk ditempet duduk yang telah disediakan oleh guru kelas tersebut. Posisi tempat duduk berada dibelakang anak-anak. Kepala sekolah tidak menggangu proses pembelajaran dengan tidak berinterkasi dengan anak dan guru. Kepala sekolah merekam saat guru mengajar dan mengisi intrumen penilaian guru. Setelah selesai kegiatan sentra kepala sekolah berpamitan kepada guru untuk keluar dari kelas tersebut.

Pelaksanaan pengamatan kelas pada guru ketiga guru kelas A3 pukul 08.00 tidak bisa dilaksankan oleh kepala sekolah dikarenakan kepala sekolah ada agenda lain.

Pelaksanaan pengaamatan pembelajaran pada guru keempat guru kelas B1. Pelaksanaan pada pukul 08.30 pada kegiatan sentra. Kepala sekolah duduk dibangku yang telah disediakan oleh guru di belakang bangku anak-anak. pembelajaran dimulai guru seperti biasa menjelaskan kegaiatan sentra di depan kelas. Kepala sekolah hanya mengamati pembelajaran dengan mengisi lembar intrumen yang telah disepakati dan kepala sekolah juga mengambil video pada saat guru menjelaskan. Setelah kegaiatan selesai kepala sekolah berpamitan dengan anakanak dan guru untuk keluar dari ruang kelas. Kepala sekolah menyeruh guru menemuinya pada saat pulang sekolah nanti untuk membahas hasil pengamatan pembelajaran hari ini.

\section{c. Tahap Diskusi}

Pelaksanaan diskusi pada guru pertema yaitu guru kelompok Play Group setelah pengamatan pembelajaran dilaksanakan setelah jam pulang anak-anak. 
Kepala sekolah dan guru bertemu kembali setelah kegiatan pengamatan pembelajaran. Sebelum memulai kepembahasan inti kepala sekolah menanyakan perasaan guru setelah melaksankan pengamatan pembelajaran oleh kepala sekolah tadi. Guru menjawab awalnya ada perasaan tidak percaya diri karena disaksikan oleh kepala sekolah langsung. Selanjutnya, baru lah kepala sekolah dan guru mulai berdiskusi mengenai hasil pengamatan pembelajaran. Kepala sekolah menunjukan hasil video guru mengajar, kepala sekolah berharap guru dapat menilai dirinya terlebih dahulu. Guru jadi tahu bagaiman dia saat mengajar dan bisa menganalisi sendiri mengapa anak-anak susah ditertibkan pada saat pembelajaran. Kepala sekolah memberi saran kepada guru agar pembelajar lebih menarik agar anak bisa tertarik dengan kegiatannya. Guru dapat mengetahui kelemahannya dimana dan perlu diperbaiki dengan bimbingan kepala sekolah. Setelah mendiskusikan hasil pengamatan, guru pamitan kepada kepala sekoalah untuk pulang.

Pelaksanaan diskusi pada guru kedua yaitu guru kelompok A1 setelah pengamatan pembelajaran dilaksanakan setelah anak-anak pulang. Kepala sekolah dan guru bertemu kembali setelah kegiatan pengamatan pembelajaran. Sebelum memulai kepembahasan inti kepala sekolah menanyakan perasaan guru setelah melaksankan pengamatan pembelajaran oleh kepala sekolah tadi. Guru menjawab awalnya ada perasaan tidak percaya diri karena disaksikan oleh kepala sekolah langsung. Selanjutnya, baru lah kepala sekolah dan guru mulai berdiskusi mengenai hasil pengamatan pembelajaran. Kepala sekolah menunjukan hasil video guru mengajar, kepala sekolah berharap guru dapat menilai dirinya terlebih dahulu. Guru jadi tahu bagaiman dia saat mengajar dan bisa menganalisi sendiri bagaimana saat guru tampil saat pembelajaran. Kepala sekolah memberi saran kepada guru membuat penilaian sesuaikan dengan kegiatan dan kegiatan yang dibuat harus menjurus pada neorosains terapan. Guru sudah tepat dalam membuat lembar penilain untuk anak dan tapi kepala sekolah harus selalui meninjau guru.

Pelaksanaan tahap diskusi pada guru ketiga tidak dilaksana karena belum melaksanakan pengamatan pembelajaran. Waktu pengamatan pembelajaran kepala sekolah tidak bisa melaksanakan karena ada agenda lain.

Pelaksanaan diskusi pada guru kedua yaitu guru kelompok B1 pada tanggal 10 Oktober 2017, setelah anak-anak pulang. Kepala sekolah dan guru bertemu kembali setelah kegiatan pengamatan pembelajaran. Sebelum memulai kepembahasan inti kepala sekolah menanyakan perasaan guru setelah melaksankan pengamatan pembelajaran oleh kepala sekolah tadi. Guru menjawab awalnya ada perasaan tidak percaya diri karena disaksikan oleh kepala sekolah langsung. Selanjutnya, baru lah kepala sekolah dan guru mulai berdiskusi mengenai hasil pengamatan pembelajaran. Kepala sekolah menunjukan hasil video guru mengajar, kepala sekolah berharap guru dapat menilai dirinya terlebih dahulu. Guru jadi tahu bagaiman dia saat mengajar dan bisa menganalisi sendiri bagaimana saat guru tampil saat pembelajaran. Kepala sekolah memberi saran kepada guru pertanyaan harus menarik misalnya mengenai lingkungan terdekat pada anak. Pengamatan ini menunjukan peningkatan pada guru, guru sudah bisa membuat anak berlomba-lomba untuk menjawab pertanyaan dari nya. Namun, guru masih perlu bimbinagn kepala sekolah agar selalu meningkatkan kemampuan profesionalismenya. 
3. Faktor Pendukung dan Faktor Penghambat Pelaksanaan Supervisi Klinis Kepala Sekolah PAUD IT Auladuna Kota Bengkulu.

Faktor pendukung pelaksanaan supervisi klinis ini baik dari kepala sekolah adalah sebagai berikut, yaitu: 1) untuk membantu menyelesaikan permasalahan pembelajaran yang di hadapi para guru, 2) ingin meningkatkan kemampuan mengajar guru, 3) agar guru lebih kretif dan inovatif dalam merencang pembelajaran. Faktor pendukung dari guru, yaitu: 1) keinginan guru untuk memperbaiki cara mengajar agar bisa memberi pelayanan-pelayanan terbaik, 2) ingin menjadi guru yang profesional dalam bidangnya, 3) Adanya jadual supervisi yang dibuat oleh kepala sekolah. Hal tersebutlah menjadi faktor yang mendukung kepala sekolah dan guru PAUD IT Auladuna Kota bengkulu terlaksananya supervisi klinis tersebut.

Factor penghambat pelaksanaan supervisi klinis dari kepala sekolah adalah jadual yang telah disepakati namun bisa jadi ada perubahan atau pembatalan karena disebabkan oleh beberapa alasan yaitu kepala sekolah ada kegiatan lain yang mendadak seperti adanya rapat yayasan, undangan ke diknas. Jadual bisa di tunda atau dibatalkan juga karena jadual guru dan kepala sekolah yang cukup padat dan biasanya guru yang akan di supervisi merasa tegang sehingga harus ada persiapan yang bagus agar nantinya mendapatkan hasil yang bagus pula. Selanjutnya, pelaksanaan supervisi klinis memakan banyak waktu jadi kadang.

\section{B. Pembahasan}

\section{Perencanaan Program Supervisi Klinis Kepala Sekolah PAUD IT Auladuna Kota Bengkulu}

Kepala sekolah PAUD IT Auladuna Kota Bengkulu belum memiliki program supervisi klinis. Kegiatan supervisi klinis hanya dilaksanakan sesuai jadual yang telah dibuat oleh kepala sekolah. Tidak memiliki program sehingga tidak jelas yang menjadi sasaran supervisi. Seharusnya kepala sekolah memiliki program supervisi yang jelas sesuai dengan permasalahan yang dihadapi oleh guru sehingga fokus pembinaan supervisi klinis lebih jelas dan ada fokusnya. Kemudian memenuhi kompetensi kepala sekolah sebagai supervisor yaitu sesuai dengan Peraturan Menteri Pendidikan dan Kebudayaan Republik Indonesia Nomor 137 Tahun 2014 tentang Standar Nasional Pendidikan Anak Usia Dini yaitu kepala sekolah merencanakan program supervisi akademik dan poin ke tujuh Melakukan pembinaan berdasarkan hasil supervisi akademik guru untuk peningkatan profesionalisme.

Pelaksanaan supervisi klinis untuk seluruh guru yang memiliki masalah baik guru senior maupun guru baru. Pelaksanaan supervisi klinis bisa dilaksanakan atas permintaan dari guru jika memang guru membutuh bantuan, selanjutnya juga kepala sekolah menawarkan untuk pelaksanaan supervisi klinis jika memang kepala sekolah melihat bahwa guru tersebut memang memiliki masalah pada saat kepala sekolah melaksanakan pengawasan pada setiap kelas. Menurut Makawimbang (2012:4) supervisi klinis tidak hanya untuk calon guru dalam pendidikan pra jabatan tetapi juga sesuai untuk guru yang sedang dalam jabatan. Pernyataan ini dapat dipahami karena masalah atau penyimpangan dalam proses belajar mengajar juga ditemui pada guru-guru yang sudah lama mengemban tugas sebagai guru. Pelayanan supervisi klinis akan lebih diperlukan untuk guru-guru kalau diadakan perubahan dan atau pembaruan dalam sistem pengajaran.

\section{Tahap Pelaksanaan Supervisi Klinis Kepala Sekolah PAUD IT Auladuna Kota Bengkulu.}

Tahapan pelaksanaan supervisi klinis kepala sekolah adalah yang pertama adalah tahap pertemuan awal untuk konsultasi 
permasalahan di hadapi guru, tahap kunjungan kelas untuk pengamatan pembelajaran, dan tahap pertemuan akhir (diskusi balikan) mengenai hasil pengamatan pembelajaran tersebut. Menurut Makawimbang (2013) menyebutkan supervisi klinis adalah suatu pembimbingan untuk meningkatkan profesionalitas guru yang dilaksanakan dengan terencana oleh guru dan supervisor yang di mulai dari tahap perencanaan awal, pelaksanaan observasi kelas, dan pertemuan akhir (diskusi balikan) yang dianalisis secara cermat, teliti dan objektif untuk mendapatkan perubahan perilaku mengajar yang diharapkan. Serta pendapat Waler dalam Purwanto (2008) yang menyebutkan tahapan supervisi klinis dari tahapan pertemuan awal, observasi pembelajaran dan diskusi balikan.

Tahap pertemuan awal yaitu kegiatan awal pelaksanaan supervisi klinis guru menemuai kepala sekolah untuk berkonsultasi atas masalah guru dalam mengajar. pertemuan ini dilaksankaan dua hari sebelum pelaksanaan pengamatan pembelajaran. pada tahap ini kepala sekolah menciptakan suasana yang akrab agar guru merasa nyaman dalam menyampaikan semua permasalan yang dihadapinya. Guru mengungkapkan permasalahan yang di hadapi kepada kepala sekolah. Guru mengungkapkan yang menjadi penyebab timbulnya permasalahan yang dihadapinya. Setelah itu kepala sekolah dan guru mendiskusikan solusi masalah tersebut. Kepala sekolah memeriksa RPPH yang telah dibuat oleh guru. Kepala sekolah akan memberi saran dan perbaikan jika memang ada yang tidak sesuai dengan SOP sekolah mengenai media, model pembelajaran, penilai anak dan lain-lain yang digunakan maka kepala sekolah meminta guru untuk memperbaiki RPPH sesuai dengan SOP sekolah yang akan digunakan pada saat observasi kelas. Selanjutnya guru menentukan fokus penilain observasi menjadi pedoman kepala sekolah pada saat penilain observasi kelas. Guru dan kepala sekolah sepakat kapan waktu pelaksanaan observasi kelas. Pertemuan guru lebih aktif dalam pelaksanaan supervisi klinis seperti dalam menentukan fokus observasi, dan juga dalam menentukan jadual pertemuan selanjutnya. Kegiatan pertemuan ini dilaksanakan di ruang kepala sekolah.

Meneurut Goldhammer, Anderson dan Krajewski dalam Makawimbang (2013) Secara teknis, ada delapan kegiatan yang harus dilaksanakan dalam perencanaan awal ini, yaitu: (1) menciptakan suasana yang akrab dan terbuka; mengembangkan aspek-aspek yang akan dikembangkan guru dalam pengajaran; (3) menerjemahkan perhatian guru dalam tingkah laku yang bisa diamati; (4) mengidentifikasi prosedur untuk memperbaiki pengajaran guru; (5) membantu guru memperbaiki tujuannya sendiri; (6) menetapkan waktu pelaksanaan observasi kelas; (7) memperjelas konteks pengajaran dengan melihat data yang akan direkam; (8) menentukan aspek-aspek yang akan di observasi kelas bersama.

Tahap kunjungan kelas kegiatan pada tahap ini yaitu kepala sekolah melaksanakan pengamatan pembelajaran pada saat guru praktik mengjar di dalam kelas. Guru menjelaskan kepada anak-anak bahwa kepala sekolah akan masuk ke kelas mereka. Kepala sekolah masuk di awal jam pembelajaran dan duduk di belakang tempat duduk anak-anak yang telah disediakan oleh guru. kepala sekolah mengamati dan mencatat fokus pengamatan mengajar guru. Kepala juga mengambil dokumentasi yaitu video dan foto. Setelah selesai keperluan observasi kepala sekolah keluar dari kelas. Seharusnya kepala sekolah keluar dari kelas ketika guru sudah menuntup kelas.

Hal ini ada beberapa yang sama dengan pendapat Pidarta (2009) mengenai 
kegiatan pada saat tahap observasi belajar, yaitu (a) persiapan, baik supervisor maupun guru bersiap-siap melaksanakan supervisi; (b) guru dan supervisor mulai memasuki ruang kelas. Guru terus mengajar dan kepala sekolah duduk di kursi belakang kelas mengamati guru mengajar; (c) sikap supervisor, supervisor harus dapat membawa diri sebaik-baikanya dalam melaksanakan supervisi klinis. Supervisor perlu berhati-hati dalam melakukan tindakan, baik sikap duduk maupun gerakgerak yang lainnya; (d) cara mengamati, supervisor ketika melakukan supervisi akan mengamati guru yang akan di supervisi secara teliti; (e) mengakhiri supervisi, pada saat sudah selesai mengajar, guru mengikuti anak-anak keluar kelas.

Tahap akhir (diskusi balikan) Kegiatan pada tahap ini yaitu tahap akhir dari pelaksanaan supervisi klinis. Kepala sekolah dan guru bertemu lagi untuk membahas hasil dari pengamatan pembelajaran setelah anak-anak pulang sekolah. tahap pertemuan akhir (diskusi balikan) langsung akan dilaksanakan pada hari yang sama dengan tahap pengamatan pembelajaran. Kepala sekolah menanyakan bagaimana perasaan guru setelah kegiatan pengamatan pembelajaran ini berlangsung. Selanjutnya, kepala sekolah menampilkan video saat guru mengajar. Dengan kepala sekolah memperlihatkan video tersebut agar guru bisa meliahat sendiri dirinya saat mengajar jadi guru dapat menafsiran diri nya saat praktik mengajar terlebih dahulu. Baru setelah itu kepala sekolah meminta guru menilai diri nya saat praktik mengajar. kepala sekolah juga memberi catatat fokus observasi kepada guru. Guru jadi tahu di mana terdapat kekurangannya, dan mendiskusikan kepada kepala sekolah. Kepala sekolah memberi bimbingan dan penguatan kepada guru agar lebih baik kedepanya dengan melihat kesimpulan dari hasil pengamatan hari itu. Hasil yang belum maksimal biasanya akan dilakukan supervisi klinis ulang, dan jika terdapat banyak kesamaan permasalahan yang dihadapi guru maka sekolah akan membuat diskusi dan pelatihan. Selanjutnya, Kepala sekolah selalu memantau perkembangan guru di sekolahnya.

Hal ini sesuai dengan beberapa kegiatan tahap akhir menurut Goldhammer, Anderson, dan Krajewski dalam Makawibang (2013) yaitu (a) menganalisis pencapaian tujuan pengajaran; (b) menganalisis target keterampilan dan perhatian utama guru; (c) supervisor menanyakan perasaan setelah menganalisis target keterampilan dan perhatian utamanya; (d) menyimpulkan hasil dari apa yang telah diperolehnya selama proses supervisi klinis; (e) guru untuk merencanakan latihan-latihan berikut sekaligus menetapkan rencana berikutnya.

Kegiatan supervisi klinis yang dilaksanakan oleh kepala sekolah untuk intrumen penilaian belum sesuai dengan yang seharusnya. Intrumen seharusnya harus sesuai dengan permasalahan yang dihadapi guru bukan menggunakan penilaian proses pembelajaran dari pembukaa, kegiatan inti dan penutup. Sehingga solusi dari permasalahan juga kurang tepat yang diberikan oleh kepala sekolah karena tidak menyelesaukan permasalahan secara tuntas.

\section{Faktor pendukung dan Penghambat Pelaksanaan Supervisi Klinis Kepala Sekolah PAUD IT Auladuna Kota Bengkulu.}

Faktor pendukung pelaksanaan supervisi klinis kepala sekolah PAUD IT Auladuna Kota Bngkulu yaitu Faktor pendukung pelaksanaan supervisi klinis ini dari kepala sekolah adalah sebagai berikut, yaitu: 1) untuk membantu menyelesaikan permasalahan pembelajaran yang di hadapi para guru, 2) ingin meningkatkan kemampuan mengajar guru, 3) agar guru lebih kretif dan inovatif dalam merencang 
pembelajaran. Faktor pendukung dari guru, yaitu: 1) keinginan guru untuk memperbaiki cara mengajar agar bisa memberi pelayanan-pelayanan terbaik, 2) ingin menjadi guru yang profesional dalam bidangnya, 3) Adanya jadual supervisi yang dibuat oleh kepala sekolah. Hal ini keinginan kepala sekolah dan guru seharusnya harus dibarengi dengan membuat program supervisi klinis khusus agar hasil supervisi maksimal.

$\mathrm{Hal}$ ini sesuai dengan Makawimbang (2013:26) supervisi klinis adalah suatu pembimbingan untuk meningkatkan profesionalitas guru, dan sama menurut Sudjana (2008:5) mendiskripsikan bahwa supervisi klinis sebagai bantuan profesional yang diberikan kepada guru yang mengalami masalah dalam melaksanakan pembelajaran agar guru tersebut dapat mengatasi masalah yang dialaminya berkaitan dengan proses pembelajaran. Selanjutnya juga sesuai dengan Acheson dan Gall tujuan supervisi klinis adalah meningkatkan pengajaran guru di kelas (Makawimbang, 2013) yaitu (a) menyediakan umpan balik yang obyektif terhadap guru mengenai pelajaran yang dilaksanakan; (b) mendiagnosis dan membantu memecahkan masalah-masalah pengajaran; (c) membantu guru mengembangkan keterampilannya menggunakan strategi pengajaran; (d) mengoreksi guru untuk kepentingan promosi jabatan ke pentingan lainnya; (e) membantu guru mengembangkan satu sikap positif terhadap pengembangan profesional yang berkesinambungan.

Faktor penghambat pelaksanaan supervisi klinis kepala sekolah PAUD IT Auladuna Kota Bengkulu di dapat data, faktor penghambat dari kepala sekolah, yaitu: 1) waktu supervisi klinis sudah ditetapkan namun ada agenda lain di sekolah sehingga pelaksanaan harus dibatalkan, 2) pelaksanaan supervisi klinis memakan banyak waktu, 3) biasanya guru yang akan di supervisi merasa tegang sehingga harus ada persiapan yang bagus agar nantinya mendapatkan hasil yang bagus pula. Faktor pengahambat dari guru, yaitu: guru terkadang merasa kurang siap dan terganggu karena belum terbiasa disupervisi klinis.

\section{KESIMPULAN}

Berdasarkan hasil penelitian dan pembahasan dapat disimpulkan bahwa pelaksanaan supervisi klinis kepala sekolah PAUD IT Auladuna kota Bengkulu adalah sebagai berikut:

1. Perencanaan program supervisi klinis Kepala sekolah PAUD IT Auladuna Kota Bengkulu belum memiliki program khusus supervisi klinis secara tertulis. Pelaksanaan supervisi klinis hanya berdasarkan jadual yang telah dibuat oleh kepala sekolah. pelaksanaan supervisi klinis berdasarkan ajuan dari guru dan kepala sekolah ketika melaksanakan supervisi umum.

2. Tahapan pelaksanaan supervisi klinis yaitu dari tahap pertemuan awal guru konsultasi permasalahan yang dihadapi guru, selanjutnya kepala sekolah melaksanakan tahap kunjungan kelas untuk pengamatan pembelajaran dan tahap pertemuan akhir (diskusi balikan), kepala sekolah memanggil guru menenai hasil pengamatan pembelajaran.

3. Faktor pendukung pelaksanaan supervisi klinis kepala sekolah PAUD IT Auladuna Kota Bengkulu adalah dari kepala sekolah adalah sebagai berikut, yaitu: 1) untuk membantu menyelesaikan permasalahan pembelajaran yang di hadapi guru, 2) ingin meningkatkan kemampuan mengajar guru, 3) agar guru lebih kretif dan inovatif dalam merencang pembelajaran. Faktor pendukung dari guru, yaitu: 1) keinginan guru untuk 
memperbaiki cara mengajar agar bisa memberi pelayanan-pelayanan terbaik, 2) ingin menjadi guru yang profesional dalam bidangnya, 3) Adanya jadual supervisi yang dibuat oleh kepala sekolah.

4. Faktor penghambat dari kepala sekolah, yaitu: 1) waktu supervisi klinis sudah ditetapkan namun ada agenda lain di sekolah sehingga pelaksanaan harus dibatalkan, 2) pelaksanaan supervisi klinis memakan banyak waktu, 3) biasanya guru yang akan di supervisi merasa tegang sehingga harus ada persiapan yang bagus agar nantinya mendapatkan hasil yang bagus pula. Faktor pengahambat dari guru, yaitu: guru terkadang merasa kurang siap dan terganggu karena belum terbiasa disupervisi klinis.

\section{Saran}

Berdasarkan pada kesimpulan yang diambil, adapun saran yang diberikan adalah sebagai berikut:

1. Bagi kepala sekolah dan guru

a. Kepala sekolah harus merancang program untuk supervisi klinis agar hasil pelaksanaan supervisi klinis sesuai dengan seharusnya.

b. Merancang kegiatan supervisi klinis dengan guru secara konkriet; kegiatan supervisi klinis perlu dilakukan secara terjadwal, terstruktur dan berkelanjutan.

c. Agar dalam kegiatan supervisi klinis mengahasilkan hal yang positif bagi perbaikan mengajar di sekolah, maka supervisor (kepala sekolah) harus mengerti dan memahami terlebih dahulu kaidah-kaidah penilainnya, baik teknis ataupun manajemen.

2. Bagi peneliti selanjutnya Penelitian ini telah mendeskripsikan pelaksanaan supervisi klinis kepala sekolah PAUD IT Auladuna Kota Bengkulu, oleh karena itu disarankan kepada peneliti selanjutnya untuk melakukan penelitian mengenai evaluasi dalam pelaksanaan supervisi klinis kepala sekolah di PAUD.

\section{DAFTAR PUSTAKA}

Bafadal, Ibrahim. 2004. Peningkatan Profesionalisme Guru Sekolah Dasar.Jakarta : Bumi Aksara.

Daryanto. 2011. Administrasi Pendididkan. Jakarta: PT Rineka Cipta.

Makawimbang, Jerry. 2013. Supervisi Klinis. Bandung: Alfabeta.

Moeleong, Lexy J. 2007. Metodologi Penenlitian Kualitatif. Bandung: P.T. Remaja Rosdakarya.

Nur Kholis, Ahmad. 2013. Supervisi Klinis. Surakarta: Oase Pustaka.

Peraturan Menteri Pendidikan dan Kebudayaan Republik Indonesia Nomor 137 Tahun 2014 Tentang Standar Nasional Pendidikan Anak Usia Dini.

Pidarta, Made. 2009. Supervisi pendidikan Kontekstual. Jakarta: Rineka Cipta.

Purwanto, Ngalim. 2009. Administrasi dan Supervisi Pendidikan. Bandung: Remaja Rosada Karya.

Sugiyon. 2006. Metode Penelitian Pendidikan Pendekatan Kuantitatif, Kualitatif, dan $R \& G$. Bandung: Alfabeta.

Sudjana, Nana. 2008. Supervisi Akademik (membina profesionalisme guru melalui supervisi klinis). Jakarta : LPP Bina Mitra 